\title{
The Factors of Residents' Support for Sustainable Tourism Development
}

\author{
Musallam Abedtalas ${ }^{* 1}$, Lokman Tobrak ${ }^{1}$, Sadık Sercek ${ }^{2}$ \\ ${ }^{1}$ Mardin Artuklu University, High School of Tourism and Hotel Management, Turkey \\ ${ }^{2}$ Dicle University, Faculty of Economics and Administration Sciences, Diyarbakir, Turkey \\ *abedtalasmus@gmail.com
}

\begin{abstract}
In this paper we examined the factors of residents' support for sustainable tourism development in Mardin city-Turkey, in the context of gender as social structure. We found that people are sensitive about positive and negative effects of tourism, in association with society attachment and involvement, with bigger role for the later. And the perceptions of positive effects reduce their evaluation of the negative effects. Also we found that women are less active in transforming their attitude toward the effects of tourism to behavior toward sustainable tourism. But they are ready, more than men, to support sustainable tourism and ignore its negative effects, in spite of their higher sensitivity for the negative effects. So we recommend raising the role of local community and giving women more chances in the different levels of tourism activities.
\end{abstract}

Keywords: Sustainable tourism development, residents' attitude, community attachment, community involvement, gender

\section{Introduction}

Economic activities use the natural and human resources to make profit, or satisfy human needs. But the human needs are infinite and resources are limited, this raises the issue of sustainable use of resources or sustainable development. Tourism also is an economic activity and raises the same problem (Amir et al., 2015). In addition, tourism is resource-intensive, so it needs a special attention as it may cause social and environmental problems (Lu and Nepal, 2009). At the same time, compared to other sectors, tourism has a high potentiality in providing (and distributing) income and creating job opportunities for women and marginalized groups, so it may be a positive factor in sustainable development (Liu et al., 2012; Zolfani et al., 2015). The concept of sustainable tourism appeared partially as a reaction to the negative effects of tourism activity and as a way to reduce those effects; it later became an appropriate approach for tourism development (Bramwell and Lane, 1993; Bramwell and Lane, 2012; Zolfani et al., 2015). In its broader term, sustainable tourism is a directive philosophy or a set of principles transferred from sustainable development into tourism (Hardy et al., 2002; Mihalic, 2014; Ruhanen, 2008). The transferring followed the publication of the Brundtland Commission's report (Our Common Future) in 1987 (Saarinen, 2006). According to this report the sustainable development is: "a development that meets the needs of the present without compromising the ability of future generations to meet their own needs" (WCED, 1987, P. 43). So the World Tourism Organization defined sustainable tourism as:

"Sustainable tourism development meets the needs of present tourists and host regions while protecting and enhancing opportunities for the future. It is envisaged as leading to management of all resources in such a way that economic, social and aesthetic needs can be fulfilled while maintaining cultural integrity, essential ecological processes, biological diversity and life support systems". (WTO, 2001, cited in Liu, 2003, P.460)

There are many different understanding of sustainability, the most important three among them are: resource based, activity based and community based. While the limits of activity are not reached yet, there is a problem in the limits of resources, to overcome this, different types of negotiation and participation of stakeholders and interested groups were used. This approach is called community approach. It "stresses the wider involvement and empowerment of various actors, especially host communities, in development by emphasizing the elements of social capital in a local context" (Saarinen, 2006, p.1130). So the stakeholders, especially host community, determine the limits of sustainable development of tourism through the negotiations and participation (Liu, 2003; Saarinen, 2006). In the community based approach the sustainable tourism is not an objective concept, but it is defined in the context of social structures where we have conflict 
interests, power relations, and different levels of knowledge among stakeholders (Tosun, 2000). For a successful sustainable development of tourism, and a continual successful functioning of this sector, one of the essential factors is the continual support of host community (Kuvan and Akan, 2005). So understanding the precedents of this support is very important (Lee, 2013). In this context the researchers refer to the importance of local factors for a successful planning and management of sustainable development of tourism, but the majority of studies about the resident attitude conducted in developed countries and developed destinations, as many researchers noted (Mason and Cheyne, 2000; Nepal, 2008; Nunkoo and Ramkissoon, 2010; Nunkoo \& Gursoy, 2012; Teye et al., 2002). Therefore it is important to study this topic in the context of developing countries and less developed destinations, to make unique characteristics and common characteristics between developed and developing countries, relating to our issue, clearest. Accordingly, choosing a tourism destination in Turkey for our study provides an important case study. In the year of 2012 Turkey was at the eleventh position by international tourism receipts (Turkish Hotelier Federation, 2013). While Turkey is considered a developing country, Mardin is less developed area relative to Turkey's general level. This represents economic and social dimensions deserve studying the factors of sustainable tourism support in their contexts. Our paper is ordered as follow: we start by introduction, followed by literature review, methodology is the third part, the fourth part is the empirical results, and at the end of it we have conclusion and implications.

\section{Literature Review}

Researchers have tried to understand the relationship between community residents' perceptions (attitude) of tourism and its impact, their support for tourism development, and the antecedents of these perceptions and support (Nunkoo and Ramkissoon, 2010; Teye et al., 2002), using many conceptual models and theories. These models include the Irridex, the Tourism Area Life Cycle TALC, social representation theory SRT, social exchange theory SET, growth machine theory, dependency theory (Choi and Murray, 2010), identity theory, and the theory of planned behavior TPB. By studying 140 articles issued between 1984-2010 on residents' attitudes to tourism Nunkoo et al. (2013) found that (56,3\%) used SET, 18.8\%, TALC 11\%, Irridix 6.3\%, Theory of reasoned action (developed to the theory of planed behavior TPB), and $4.7 \%$ Social representation theory. Irridix tried to explain the negative attitude of residents toward tourism by the increasing number of tourists with the development of the destination. However, many researchers questioned the validity of Irridix and showed results contradicted this model (García et al., 2015). For TALC model, which explained the negative attitude by the advanced stage of life cycle of the destination, its applications gave different results (García et al., 2015). These two frames may not be beneficial for our paper, as our case study is less developed destination.

The Social exchange theory SET suggests that the residents are likely to support tourism development as long as they perceive that its benefits will be more than its costs, individually and socially. These costs and benefits are economic, socio-cultural and environmental (Choi and Murray, 2010; Easterling, 2004; Harrill, 2004; Nunkoo and Ramkissoon, 2010). The majority of empirical studies supported SET (Chhabra, 2007; lee, 2013; Weaver and Lawton, 2013; Yoon et al., 2001) but some showed mixed results (Andereck et al., 2005). In addition, Sharpley (2014) questioned the applicability of the theory when there is no connection between tourists and residents. Also Nunkoo and Ramkissoon (2010, P. 246) considered that using attitudes to understand the support for tourism omit the "explicit reference to the self-identity". Thus some researchers suggest social representations theory as alternative (Sharpley, 2014) or complementary (Weaver and Lawton, 2013) for SET. This means that there is no consensus about this theory, though its dominance. Social representations theory SRT proposes that attitudes reflect underlying social representations of reality which are widely shared in society. They are shared perceptions of the nature of phenomena and the cause of events (Dickinson and Dickinson, 2006; Weaver and Lawton, 2013). This theory used and supported by some studies (Perez and Nadal, 2005; Weaver and Lawton, 2013), but the measures of social representations are neither clear nor unified. According to the theory of planed behavior TPB, which is an advanced version of the theory of reasoned action, which was used and supported by (Dyer et al., 2007); the internal factors such as an individual's attitude towards the behavior, subjective norms and perceived behavioral control are the determinant of support for tourism, but this theory is not widely tested in the area of tourism support (Nunkoo and Ramkissoon, 2010). However, in the view of traditional structuralism and post structuralism, the contextual factors or social structures shape the behavior of individuals and groups. These factors may be 
economic, as in the view of Marxist structuralism, culture, power, space and place (Davis, 2001). In this context, gender is one of the important social structures and its role deserves studying.

In post-modernism views of the world "we no longer have dominant paradigms that change through time as much as we have multiple paradigms juxtaposed at a given time" (Davis, 2001, p. 131). So we should not be informed only by one or two theories in tourism, especially, relating to residents' attitude toward tourism, rather we should be informed by many theories. Accordingly, based on a mix of previous theories as a background, we suggest a mixed model MM, as in the figure (1). Initially we assume that people are rational in their behavior and decision, using the available information to make the best decision. But as we know people have different rationalities, different ideas, different values, and different information; depending on differences in the natural abilities and social contexts, where they live and interact. So we expect that the attitude toward sustainable tourism is built starting from a different sensitivity of people to tourism effects, followed by the attitude toward these effects, and reaching to the behavior or decision of supporting tourism or opposing it. This process, as a whole proceeds in and conditioned by the social contexts. So we need to be informed by theoretical frameworks that link the variables and stages of this process (Moscardo, 2011; Nunkoo and Ramkissoon, 2010). Therefore, we need to mix socio-structural (socio-economic) and socio psychological (attitudes, beliefs and values) approaches (Dietz et al., 1998, cited in Dickinson and Dickinson, 2006).

The negative and positive effects, or costs and benefits, of tourism are divided into three groups: economic, socio-cultural and environmental (Andereck et al., 2005). Each group has its own positive and negative aspects. The majority of researchers studied the relationship between the general perceived effects as two groups, positive and negative, and support for tourism. They found a significant negative relationship for the negative perceived effects and a significant positive relationship for the positive perceived effects (Choi and Murray, 2010; Gursoy, 2004; Gursoy, 2006; Jurowski, 2004; Koa and Stewart, 2002; Lee, 2013; Sanchez et al., 2011). Only (Gursoy, 2006) found that the negative relationship between costs and support is not significant. Other researchers used the positive and negative impacts and their economic, socio-cultural and environmental aspects separately or used only some of them (Dyer et al., 2007; Gursoy, 2004; Yoon et al., 2001). The results were not supportive for all aspects. Therefore, in line with SET and TPB which refer to the importance of attitude (perceived negative and positive impacts) in forming the behavior (supporting tourism) (Nunkoo and Ramkissoon, 2010), we suggest the following two hypotheses:

H1: A positive relationship exists between perceived positive impacts of sustainable tourism (perceived benefits PB) and residents' support for sustainable tourism development (STD).

H2: A negative relationship exists between perceived negative impacts of sustainable tourism (perceived costs PC) and residents' support for sustainable tourism development (STD).

According to Gursoy $(2006$, p. 610) "the most salient impact is likely to influence the perception of all other impacts", however, he couldn't support this idea empirically. For Mardin, as tourism is a mean of economic development and improving the well-being of society, we expect that people perceiving of those positive impacts of tourism may reduce their evaluation of the negative impacts. Therefore, we propose the following hypothesis:

H3: A negative relationship exists between perceived positive impacts PB and perceived negative impacts PC of sustainable tourism development.

For McCool and Martin (1994) cited in (Harill, 2004) community attachment is "extent and pattern of social participation and integration into community life, and sentiment or affect toward the community", this may contain many elements of "emotion, affect, meaning, feeling, bonding, and value" (Nicholas et al., 2009, p. 395). In the view Kyle et al. (2004) cited in (Lee, 2013, p. 38), the residents' "attachment to their community is demonstrated through the concepts of community identity, community dependence, social bonding within a community, and affective responses to feelings regarding a community". Therefore, community attachment plays an important role in residents' attitude toward society development (Nicholas et al., 2009), and then sustainable tourism development. This is in line with SRT which refers to the role of a stock of shared values, ideas, beliefs, and practices inside a society or group's member, in the attitude (Dickinson and Dickinson, 2006; Weaver and Lawton, 2013); and TPB, which says "if the individual perceives that his or her family, friends or members living in a community encourages such support for tourism, he or she will be more 
willing to support such development" (Nunkoo and Ramkissoon, 2010, p. 530). The Measures of community attachment and its relationship with tourism development deferred among researchers (Nicholas et al., 2009). Some researchers used the birth place and length of staying to measure the attachment (Davis et al., 1988; Jurowski et al., 1997; Lankford and Howard, 1994; Liu and Var, 1986; McCool and Martin 1994; McGehee and Andereck 2004; Sheldon and Var, 1984; cited in Andereck et al., 2005 and García et al., 2015), though McCool and Martin (1994) cited in (Mason and Cheyne, 2000) did not find a clear relationship between community attachment and length of residence. Others used self-evaluation items in the questionnaire (Choi and Murray, 2010; Gursoy and Kendall, 2006; Gursoy and Rutherford, 2004; Lee, 2013; Nicholas et al., 2009). Some researchers studied the direct relationship between community attachment and support for tourism (Nicholas et al, 2009), others mediated the perceived costs and benefits between them (Choi and Murray, 2010; Gursoy and Kendall, 2006; Gursoy and Rutherford, 2004; Jurowski and Gursoy, 2004).

Liu and Var (1986), Sheldon and Var (1984), and Um and Crompton (1987) cited in (Mason and Cheyne, 2000) reported that a longer residency is associated with negative stance toward tourism development. On the other hand, while McCool and Martin (1994) cited in (Mason and Cheyne, 2000) found that more attachment means higher evaluation of positive and negative effects of tourism, Davis et al. (1988) cited in (Tosun, 2002) reported that the attached people are more positive about tourism than the less attached ones. However, Lankford and Howard (1994) cited in (Tosun, 2002) found no significant relationship between the two. According to Nicholas et al. (2009) results, there is a positive direct relationship between community attachment and support for tourism. Choi and Murray (2010) findings, referred to a direct and indirect positive relationships between community attachments and tourism. Gursoy \& Rutherford (2004) reported that community attachment has a positive relationship with perceived positive economic and social impacts but has no relationships with perceived social and cultural negative impacts and perceived positive cultural impacts. Gursoy and Kendall (2006) and lee (2013) reported no significance relationships between community attachment and perceived cost, but they found a positive relationship between community attachment and perceived benefit of tourism development. So there is no consensus among researchers on this topic. But in recent studies they tend to show the existence of a positive relationship (directly or indirectly by perceived benefits) between community attachment and tourism development. In this context, as our case study is less developed and sustainable development represents an opportunity for developing the area, we suggest, using self-evaluation items to measure attachment, and in line with TSR and TPB, the following hypotheses:

H4: A positive relationship exists between community attachment CA and perceived positive impacts PB of sustainable tourism development.

H5: A negative relationship exists between community attachment CA and perceived negative impacts PC of sustainable tourism development.

H6: A positive direct relationship exists between community attachment CA and residents' support for sustainable tourism development STD.

By applying the TPB in the context of tourism Nunkoo and Ramkissoon (2010, p. 530) conclude that, as the power of residents affects their support for tourism development, "the greater the individual perceives that he or she has control over his or her behavior towards tourism, he or she would be more willing to support tourism development". According to Nelson (1993) cited in Choi and Murray (2010) the participation of residents in decision making is a basic signal for sustainable tourism. Nicholas et al. (2009, p. 396) referred to the same idea saying: "community involvement-in tourism planning and management - is considered to be the cornerstone of sustainable tourism development". Many researchers explored the relationship between community involvements and tourism. Choi and Murray (2010) studied the role of community participation, and found no direct relationship between community participation and support for tourism, but there was a negative relationship between community participation and positive impacts of tourism, and a positive relationship between community participation and negative impacts of tourism. But Nicholas et al., (2009) could not find a direct or indirect relationship. However, Lee (2013) studied the indirect relationship by mediating perceived benefits and costs, and assured the existence of indirect positive relationship between community involvement and sustainable tourism development through perceived benefits. As there are no clear cut results in this area we suggest the following hypotheses:

H7: A positive relationship exists between community involvement CI and perceived positive impacts PB of 
sustainable tourism development.

H8: A negative relationship exists between community involvement and perceived negative impacts PC of sustainable tourism development.

H9: A positive direct relationship exists between community involvement CI and residents' support for sustainable tourism development STD.

Gender as a social structure plays an important role, especially in the developing countries. The Marxist view says that class differences, in capitalism system of production, are the mechanism that enables men to restrict women from work, income and independence; and structures labor force hierarchically. Others say the patriarchal relations determined women access to occupations. Or we can say that the capitalist hierarchy and patriarchy both shape the gender role (Chhabra, 2007; Kinnaird and Hall, 2000), and affect the ideas, values and behavior of humans. Also Nunkoo and Ramkissoon (2010) say, in the context of TPB, that the inequality of power between men and women, and then the differences in their control over tourism may lead to differences in their support for tourism development (Alonso, 2015). In empirical studies, Mason and Cheyne (2000) found that the women are less supportive of tourism development. Also Nunkoo and Gursoy (2012) found no effect of gender on the attitudes of positive impacts but it affects the attitudes of negative impacts of tourism. And the women were more negative. However, they considered gender as one of socio-demographic factors, which may affect, but not general social structure that makes the context of the whole process. Relating to the role of gender, in line with structuralism and post structuralism, we consider gender as one of social structures that shapes the interaction between sustainable tourism development and local community, and suggests the following hypothesis;

H10: there are significant differences between men and women in their attitudes and behavior toward sustainable tourism development.

\section{Methodology}

Study Site and Context is Mardin city in Turkey. Mardin is located in Southeast Anatolia. It is one of the most important cities in Turkey with its natural beauties, cultural heritage and socio-cultural elements. It was added to a tentative list of Unesco World Heritage sites. It has a unique population diversity in Turkey. Kurds, Arabs, Turks, Assyrians, Christians, and Muslims live in the city. But there are many obstacles for tourism development, such as weak human resources and transport infrastructure, lack of diversified tourism products, non-availability of tourism information (Toprak et al., 2014, 114-137). Mardin is a less developed area, relative to Turkey in general, by economic and social measures. The social structure is characterized by large nuclei families composed of 8 members (Toprak et al., 2014, 114-137). According to an EU report in 2013 there are the following indications about the situation of gender equality in Turkey: The general employment rate of women in the Turkish labor market (28.7\%) in 2012, the EU-27-average (58.6\%). Tertiary education attainment of women in Turkey is $10.6 \%$ in 2012 , the EU-27-average $25.8 \%$. Gender pay gap is between $10 \%$ and $30 \%$ in favor of men. And the shares of women in the management positions are $7.0 \%$, the EU-27 average 33.0\%. And we expect the situation will be worse in Mardin, as it is less developed area in Turkey.

According to Turkey Tourism Strategy- 2023 (Ministry of Culture and Tourism- 2007, pp 11-13) Turkey will adopt a sustainable tourism approach and will aim at the same time to "leverage the rates of employment and regional development ........To become a world brand in tourism and a major destination in the list of top five countries, receiving the highest number of tourism and highest tourism revenues by 2023". There is an important role for local community residents in facilitating the execution of this strategy, and raising the contribution of the tourism sector to the local economy, in the context of sustainable tourism development. So it is important to understand the attitude of Mardin resident toward sustainable tourism development; as it belongs to a developing country (Turkey), less developed as a tourism destination, and less developed by socio- economic measures, specially relating to gender. Therefore, it is a good case study for our paper. We used a questionnaire, previously used by Lee (2013). We feel that this questionnaire is suitable for our paper for two reasons. Firstly, to be able to make a reasonable comparison with Lee (2013), as this research conducted in a developing country. Secondly, this questionnaire covers the variables that we want to study. In addition, we discussed the questionnaire with five of teaching staff members of High School of Tourism and Hotel Management- Artuklu University, and they agreed that the questionnaire is suitable for this study. The 
questionnaire contains /32/ items in addition to socio-demographic characteristics. Five items to measure support for sustainable tourism development, three for perceived costs, ten for perceived benefits, four for community involvement and ten for community attachment.

The research was conducted in Mardin city between April and May 2015, by simple random sampling, and face to face questionnaire, by the authors. We tested the people understanding for the questionnaire by a sample of 50 people, and found a good understanding. Five strategic locations were chosen to conduct the questionnaire, as we expect that the majority of Mardin people should pass through these locations (the biggest mall in Mardin, the governorship gate, the government hospital yard, the old Mardin bus terminal and the biggest public garden in Mardin). About 20\% of people, who were asked to fill the questionnaire, accepted to do, as they were busy or they did not like to do. We could get 900 filled questionnaire, 66 (or 7\%) were not completed, and 834 (or 93\%) were valid. We used SPSS 21 and AMOS and Structural Equation Model to analyze and test our hypotheses. "Structural equation modeling (SEM) is a technique for simultaneously estimating the relationships between observed and latent variables (the measurement model), and the relationships among the latent variables (the structural model). SEM is a method that has gained popularity because it combines confirmatory factor analysis and regression analysis to model the variety of psychological, sociological, and other relationships" (Lindberg and Johnson, 1997, cited in Koa and Stewart, 2002).

\section{Results}

Our population was Mardin city population, /383984/in the year of 2014, for Artuklu and Kiziltepe districts (Turkish Statistical Institute website). For demographic profile of the respondents, our sample size was /834/, among them 352 (42,2\%) women and 482(57,8\%) men, the ratio for Turkey as a whole was 49,8\% and $50,2 \%$ relatively for the year of 2014(Turkish Statistical Institute website), the majority of them were single $(51,3 \%)$ In terms of age $(44,40 \%)$ were between $18-25,(24,90 \%)$ between $26-35,(17,70 \%)$ between $36-45,(9,60 \%)$ between $46-55$ and $(3,40 \%) 56$ and more. Relating to education $(27,1 \%)$ completed university level education. This means that the sample is balanced relative to Mardin society, as it is a young society with high fertility rates and the restricted activity for women outside home. Relating to the measurement model which relates the observed variables to latent variables, we conducted the confirmatory factor analysis CFA, and the results are shown in table (1). The loading of factors was between /0,74-0,93/ and $/ \mathrm{P}<0,05 /$, which means the convergent validity, as they are more than $/ 0,60 /$ (Nicolas, 2009). The Cronbach's alpha values refer to the internal consistency, as they are between $(0,74-0,96)$, and more than the threshold of (0.70) (Nunnally, 1978; cited in Nicolas, 2009). The average variance extracted AVE values ranged between /0,66-0,80/, also are more than the accepted value of /0.50/ (Fornell and Larcker, 1981; cited in Nicolas, 2009) these mean good validity and reliability. For the goodness of fit of the model we used the indices used by Nicolas, (2009), and got Chi-square $=1195,15$, Degrees of freedom $=451$ and Probability level $=0,000$ which implies that the measurement did not fit the data well, but Chi square $/ \mathrm{df}=2,65$ is good indicator as it is less than threshold 3, the comparative fit index (CFI) was 0.92 (more than 0.90) and the root mean square error of approximation (RMSEA) of 0.063 (less than 0.08 ) are also good indicators of fitness.

We estimated the structural model, using the whole sample. The table (2) is showing the results. The goodness of fit of the model is measured by the same indices as a measurement model. Chi-square $=1312,41$, Degrees of freedom $=451$, Probability level $=0,000$, Chi-square $/ \mathrm{df}=2,91$ the comparative fit index (CFI) of 0.93 and the root mean square error of approximation (RMSEA) of 0.067 , which means acceptable level of fitness, though chi-square is not good. As we can see in the table /2/ our hypotheses 1, 2, 3,4,5,7, 9 are supported at the significant level of 0.05 , the hypotheses 6 and 8 is refused at the significant level of 0.05 . To test hypothesis10 we conducted the multi-group analysis, which is used in SEM to test whether the parameters are equivalent (or invariant) across groups, or whether the same theories is valid across groups in the same ways. According to Byrne, $(2004$, p272) "it is typically assumed that the instrument of measurement is operating in exactly the same way, and that the underlying construct being measured has the same theoretical structure for each group under study. As evidenced from reviews of the literature, however, these two critically important assumptions are rarely, if ever, tested statistically. One approach to addressing this issue of equivalence is to test for the invariance of both the items and the factorial structure across groups using the analysis of covariance ....structures. As such, one would test for the equivalence of all items 
designed to measure the construct underlying each subscale.., as well as relations among these underlying constructs". We grouped our sample by gender and estimated full constrained and unconstrained models, after omitting the insignificant path of community attachment to sustainable tourism support, compared the Chi-square and degrees of freedom, and made decision about existence of significant difference between the two groups. As we can see in the table /3/panel (a), there is a significant difference, this allows us to go ahead and test the whole paths over the two groups. And there are significant differences between men and women for all paths. This supports hypothesis 10.

Our results about association of residents' perceptions for benefits and costs of sustainable tourism development and their support for sustainable tourism development, are correspond with the results of the majority of previous studies (Choi and Murray, 2010; Gursoy and Kendall, 2006; Gursoy and Rutherford, 2004; Lee, 2013, Nicholas et al., 2009; Nunkoo and Ramkissoon, 2010) that there is a negative association for costs and a positive association for benefits. These support Lee's, $(2013$, p.42) findings about the "international and multicultural perspectives on community-based sustainable tourism development". But as we can see in table /4/, which compares our results with those of Lee, (2013) as a study of developing country but developed destination with a sample of tourism involvement people, and Choi and Murray, (2010) as a study of developed country, the people in a developed country and developed destination are less supportive of tourism. We expect this to be, in line with Irridix and TALC, a result of the level of countries and destinations development. In addition the more involved people may be more aware of the positive and negative effects of tourism. The negative association between PB and PC, may be explained by the fact that people start thinking about tourism as beneficial economic activity and later they realize its costs, or they ignore the negative effect as it is small at the first stage. This finding is somehow new as we could not find it in previous studies.

For community attachment, as we noted in the literature review the studies reflected different findings. We found an insignificant positive direct relationship which was significant in Choi and Murray, (2010) and Nicolas et al. (2009). Considering the association of CA and PB and PC, we found a positive association and a negative association respectively. This agrees partially with Gursoy and Kendall, (2006) and Lee, (2013), as they could not find a significant relationship for PC. From table /4/ we see that in the cases of Choi and Murray, (2010) and Lee, (2013) there is a stronger positive association between CA and PB, and a stronger negative relationship with PC for Choi and Murray, (2010) with no relationship for Lee, (2013), compared with ours. We relate this to the degree of destination development and using additional variables for the first and tourism involvement of the sample in the second, also may it be related to the dependency on tourism as a source of income directly or indirectly, as we expect that this dependency reduced the sensitivity of Lee, (2013) sample for this path. By exploring the role of community involvement, there was a positive direct association between CI and STD, which means that the involved people may support tourism, without making special attitude toward its effects, while Choi and Murray (2010) and Nicolas et al. (2009) found an insignificant negative association. So we can say that more involved people may be more positive about tourism, regardless of their attitude. For the association between CI and PB and PC, there was a positive association. This is in line with the results of Lee, (2013) for the PB and Choi and Murray (2010) for PC, but it was at the opposite of Choi and Murray (2010) for PB. For our results it could be explained by the increasing level of knowledge about the negative and positive effects of tourism, with more involvement, and the level of destination development, as our case study is at the starting level and there are not much negative experiences yet.

While we used gender as a social structure that shapes the model and its variables as a whole, the previous studies used it as one of the demographic characteristics. Table /3/ panel (2) shows significant differences between men and women. Considering the paths of effects of perceived cost and perceived benefits on sustainable tourism development, the women are less able to turn their attitudes to effective behavior toward tourism. We can explain this result by the level of social development of Mardin society and the constraints on the behavior and rights of women. For the path of the relationship between community involvement and STD, we can see that with higher involvement the women provide a stronger direct support for STD than men and their sensitivity for PC increases with the increase of involvement more than men, while men are more sensitive for the positive effects. This means higher readiness of women to support tourism, as a chance for better future, without make a special attitude toward cost and benefits. In addition with the increase in 
women knowledge by the involvement they became more sensitive for the negative effects of tourism. By looking at the relationship between PB and PC, we find a balanced view of the two by men, as there is no significant relationship, but for women there is a negative significant relationship. This reflects the different chances available for men and women to get knowledge for the interest of men, as the evaluation of negative effects needs higher level of knowledge than the positive ones, in addition to tourism as good chance for women. For CA there are not important differences between men and women relating to the relationships with $\mathrm{PB}$, though it is somehow stronger in the case of men. But there is negative relationship with costs, this means with more attachment women are ready, more than men, to ignore the negative effects of tourism and provide support for it.

\section{Conclusion and Implications}

In this paper we tested /10/ hypotheses, relating to the resident's attitude toward sustainable development of tourism and its antecedents and social context. To contribute to the efforts that try to understand this phenomenon; /8/ of our hypotheses were accepted, while two were refused. And our model after testing is showed in the figure 2. The first three hypotheses were informed by SET and TBP. They were accepted, which means that people compare between the cost and benefits of sustainable tourism and support it if the benefits are more than the costs. This confirms SET. Also the third hypothesis suggests that people appreciate benefits more than costs and they may ignore the cost because of the benefits. However, as there is a significant direct association between community involvement and support for sustainable tourism development, we can say that not only the perceptions of costs and benefits determine the support; there are other factors, such as community involvement. This path assures the TBP. For the community attachment, the hypotheses 4 and 5 were accepted, which means that more attached people tend to appreciate the positive effects of tourism and depreciate the negative effects. This supports TSR and TPB. However, the hypothesis 6 was refused, suggesting no direct relationship between CA and STD. Relating to the community involvement the hypotheses 7 and 9 were accepted while the opposite of hypothesis 8 was acceptable, which means the more the involvement, the greater the appreciation of benefits and costs of tourism will be, with strongest effect for benefits. This also suggests supporting TPB, which refers to the role of control over the behavior in supporting it. Generally, there are indirect relationship between CA and STD, and direct and indirect relationship between CI and STD, with a stronger role for CI. The acceptance of hypothesis 10 means that gender as a social structure is one of the important contexts that shape the sustainable tourism supporting and its factors, and the interaction between them. This supports the using of structuralism and post structuralism in the context of tourism.

In general, we note that the theories which informed us supported partially, as they could explain the results together. This supports our dependence on the postmodernism view. And this gave us some new idea about this issue. Firstly, people in the developing countries and less developed destinations are less sensitive to the positive and negative effects of tourism, in association with society attachment. But with more involvement their knowledge and sensitivity increases. Secondly, people in developing countries and less developed people, with seeing the positive effects, reduce their evaluation of the negative effects. Thirdly, women are less active in transforming their attitude toward the positive and negative effects of tourism to support for sustainable tourism. But they are ready, more than men, to support sustainable tourism and ignore its negative effects, though their higher sensitivity to negative effects with more involvement. Depending on these results we can recommend the tourism decision makers to concentrate their efforts on raising the role of local community in all stages of tourism activities, especially giving women more chances in different levels of activities: planning, controlling, and managing. And increase promotion activities, such as festivals, conferences, sport events, in addition to developing tourism education with its different levels (technical and high) that contribute in developing the local resident's involvement in and their knowledge about tourism and their attachment to the community. And provide more support for small projects in tourism especially that is owned by women, such as studying the investment opportunities in this field and provide financial and technical facilities

In generalizing the results of this study there is some limitations should be taken into account. The limitations of this study were the using of (Lee, 2013) questionnaire with only three items for perceived costs, which is the minimum accepted level, and may affect the reliability of the scale. The other limitation is collecting data 
from the street and the low level of response. The third limitation was collecting the data only from Mardin city, excluding villages. The last two limitations may affect the representativeness of the sample. So we expect it will be better for future studies to overcome these limitations, and conduct study with more developed questionnaire, with samples cover villages. In addition, because we could not study the role of all social structures, we expect it will be beneficial for future studies to make more searches about local resident's support for sustainable tourism development in the context of different social structures and other tourism destinations.

\section{References}

Alonso, A. D., Sakellarios, N. \& Pritchard, M. (2015). The theory of planned behaviour in the context of cultural heritage tourism. Journal of Heritage Tourism, 10(4), 399-416.

Amir, A. F., Abd Ghapar, A., Jamal, S. A. \& Ahmad, K. N. (2015). Sustainable tourism development: A study on community resilience for rural tourism in Malaysia. Procedia - Social and Behavioral Sciences, 168, 116 - 122.

Andereck, K. L., Valentine, K. M., Knopf, R. C. \& Vogt, C. A. (2005). Resident's' Perceptions of Community Tourism Impacts. Annals of Tourism Research, 32(4), 1056-1076.

Bianchi, R.V. (2009). The 'Critical Turn' in Tourism Studies: A Radical Critique. Tourism Geographies, 11(4), 484-504.

Bramwell, B. \& Lane, B. (1993). Sustainable tourism: An evolving global approach. Journal of Sustainable Tourism, 1(1), $1-5$.

Bramwell, B. and Lane, B. (2012). Towards innovation in sustainable tourism research? Journal of Sustainable Tourism, 20(1), 1-7.

Byrne, B. M. (2004). Testing for Multigroup Invariance Using AMOS Graphics: A Road Less Traveled. Structural Equation Modeling: A Multidisciplinary Journal, 11(2), 272-300.

Chhabra, H. (2007). Gendered Social Exchange Theory Variations across the Life Span in Casino Settings. Anatolia, 18(1), 145-152. doi: 10.1080/13032917.2007.9687042.

Choi, H. C. \& Murray, I. (2010). Resident attitudes toward sustainable community tourism. Journal of Sustainable Tourism, 18(4), 575-594.

Davis, J. B. (2001). Commentary: Tourism research and social theory - expanding the focus. Tourism Geographies, 3(2), 125-134.

Davis, D., Allen, J. \& Cosenza, R. M. (1988). Segmenting local residents by their attitudes, interests, and opinions toward tourism. Journal of Travel Research, 28(2), 2-8.

Dickinson, J. E. \& Dickinson J. A. (2006). Local Transport and Social Representations: Challenging the Assumptions for Sustainable Tourism. Journal of Sustainable Tourism, 14(2), 192-208.

Dietz, T., Stern, P. C. \& Guagnano, G. A. (1998). Social structural and social psychological bases of environmental concern. Environment and Behavior, 30(4), 450-71.

Dyer, P., Sharma, B. \& Carter, J. (2007). Structural modeling of resident perceptions of tourism and associated development on the Sunshine Coast, Australia. Tourism Management, 28, 409-422. doi:10.1016/j.tourman.2006.04.002

Easterling, D. S. (2004). The Residents' Perspective in Tourism Research. Journal of Travel \& Tourism Marketing, 17(4), 45-62.

Fornell, C. \& Larcker, D. (1981). Evaluating Structural Equation Models with Unobservable Variables and Measurement Error. Journal of Marketing Research, 18(1), 39-50.

García, F. A., Vázquez, B. A. \& Macías, R. C. (2015). Resident's attitudes towards the impacts of tourism. Tourism Management Perspectives, 13, 33-40.

Gursoy, D. \& Rutherford, D. G. (2004). Host attitudes toward tourism: an improved structural model. Annals of Tourism Research, 31(3), 495-516.

Gursoy, D. \& Kendall, K. W. (2006). Hosting mega events: modeling locals' support. Annals of Tourism Research, 33(3), 603-623.

Hardy, A., Beeton, R. J. S. \& Pearson, L. (2002). Sustainable Tourism: An Overview of the Concept and its Position in Relation to Conceptualizations of Tourism. Journal of Sustainable Tourism, 10(6), 475-496.

Harrill, R. (2004). Residents' Attitudes toward Tourism Development: A Literature Review with Implications for Tourism Planning. Journal of Planning Literature, 18(1), 1-16.

Jurowski, C. \& Gursoy, D. (2004). Distance effects on residents' attitude toward tourism. Annals of Tourism Research, 31(2), 296-312.

Jurowski, C., Uysal, M. \& Williams, R. (1997). A theoretical analysis of host community resident reactions to tourism. Journal of Travel Research, 36(2), 3-11.

Kinnaird, V. \& Hall, D. (2000). Theorizing Gender in Tourism Research. Tourism Recreation Research, 25(1), 71-84.

Koa, D. W. \& Stewart, W. P. (2002). A structural equation model of residents' attitudes for tourism development. Tourism Management, 23,521-530.

Korca, P. (1996). Resident Attitudes toward Tourism impacts. Annals of Tourism Research, 23(3), 596-726. 
Kuvana, Y. \& Akan, P. (2005). Residents' attitudes toward general and forest-related impacts of tourism: the case of Belek. Antalya, Tourism Management, 26, 691-706.

Kyle, G., Mowen, A. J. \& Tarrant, M. (2004). Linking place preferences with place meaning: an examination of the relationship between place motivation and place attachment. Journal of Environmental Psychology, 24, 439-454.

Lankford, S. V. \& Howard, D. R. (1994). Developing a tourism impact attitude scale. Annals of Tourism Research, 21(1), 121-139.

Lee T. H. (2013). Influence analysis of community resident support for sustainable tourism development. Tourism Management, 34, 37-46.

Lindberg, K. \& Johnson, R. L. (1997). Modeling resident attitudes toward tourism. Annals of Tourism Research, 24(2), 402-427.

Liu, C. H., Tzeng, G. H. \& Lee, M. H. (2012). Improving tourism policy implementation - The use of hybrid MCDM models. Tourism Management, 33, 413-426.

Liu, J. \& Var, T. (1986). Resident attitudes toward tourism impacts in Hawaii. Annals of Tourism Research, 13(2), $193-214$.

Liu, Z. (2003). Sustainable Tourism Development: A Critique. Journal of Sustainable Tourism, 11(6), 459-475.

Lu, J. \& Nepal S. K. (2009) Sustainable tourism research: analysis of papers published in the Journal of Sustainable Tourism. Journal of Sustainable Tourism, 17(1), 5-16.

McCool, S. F. \& Martin, S. R. (1994). Community attachment and attitudes toward tourism development. Journal of Travel Research, 32(3), 29-34.

McGehee, N. \& Andereck, K. (2004). Factors predicting rural residents' support of tourism. Journal of Travel Research, 43(2), 131-140.

Mason, P. \& Cheyne, J. (2000). Residents' attitude to proposed tourism development. Annals of Tourism Research, 27(2), 391-411.

McCool, S. F. \& Martin, S. R. (1994). Community attachment and attitudes toward tourism development. Journal of Travel Research, 32(3), 29-34.

Mihalic, T. (2014). Sustainable-responsible tourism discourse - Towards 'responsustable' Tourism. Journal of Cleaner Production, xxx, 1-10. doi:10.1016/j.jclepro.2014.12.062

Ministry of Culture and Tourism. (2007). Turkey Tourism Strategy- 2023.

Moscardo, G. (2011). Exploring social representations of tourism planning: issues for governance. Journal of Sustainable Tourism, 19(4-5), 423-436.

Nelson, J. G. (1993). An introduction to tourism and sustainable development with special reference to monitoring. In J.G. Nelson, R. Butler, and Wall, G. (Eds.), Tourism and sustainable development: Monitoring, planning and managing (pp. 3-23). Waterloo, Canada: Department of Geography Series.

Nepal, S. (2008). Residents' attitudes to tourism in Central British Columbia, Canada. Tourism Geographies, 10, 42 -65.

Nicholas, L. N., Thapa, B. \& Ko, Y. J. (2009). Residents' Perspectives of World Heritage Site: The Pitons Management Area, St. Lucia. Annals of Tourism Research, 36 (3), 390-412.

Nunnally, J. (1978). Psychometric theory, 2nd ed., New York: McGraw-Hill.

Nunkoo, R. \& Ramkissoon, H. (2010). Gendered theory of planned behaviour and residents' support for tourism. Current Issues in Tourism, 13(6), 525-540.

Nunkoo, R. \& Gursoy, D. (2012). Residents' support for tourism: an identity perspective. Annals of Tourism Research, $39(1), 243-268$.

Nunkoo R., Smith S. L. J. \& Ramkissoon H. (2013). Residents' attitudes to tourism: a longitudinal study of 140 articles from 1984 to 2010. Journal of Sustainable Tourism, 21(1), 5-25.

Perez, E. A. \& Nadal, J. R. (2005). Host Community perceptions: A Cluster Analysis. Annals of Tourism Research, 32 (4), 925-941. doi:10.1016/j.annals.2004.11.004

Ruhanen, L. (2008). Progressing the Sustainability Debate: A Knowledge Management Approach to Sustainable Tourism Planning. Current Issues in Tourism, 11(5), 429-455.

Saarinen, J. (2006). Traditions of Sustainability in Tourism Studies. Annals of Tourism Research, 33(4), 1121-1140.

Sanchez, A. V., Bueno, N. P. \& Mejia, M. A. P. (2011). Explaining Residents' Attitude to Tourism: Is a universal model possible? Annals of Tourism Research, 38(2), 460-480.

Sharpley, R. (2014). Host perceptions of tourism: A review of the research. Tourism Management, 42, 37-49.

Sheldon, P. J. \& Var, T. (1984). Residents' attitudes toward tourism in North Wales. Tourism Management, 5(1), 40-47.

Stoddard, J. E., Pollard, C. E. \& Evans M. R. (2012). The Triple Bottom Line: A Framework for Sustainable Tourism Development. International Journal of Hospitality \& Tourism Administration, 13(3), 233-258.

Teye, V., Sönmez S. \& Sirakaya, E. (2002). Resident Attitudes toward Tourism Development. Annals of Tourism Research, 29(3), 668-688.

Toprak, L., Aykol, Ş. \& Yarıș, A. (2014). Mardin İlinde Sektörel Kalkınmanın Yeniden İnşası, Ankara Araştırmaları Enstitüsü.

Tosun, C. (2002). Host perceptions of impacts: A comparative tourism study. Annals of Tourism Research, 29(1), $231-253$.

Tosun, C. (2000). Limits to community participation in the tourism development process in developing countries. Tourism Management, 21, 613-633. 
Turkish Hotelier Federation. (2013). Tourism report. Turkish Statistical Institute website, http://www.turkstat.gov.tr/UstMenu.do?metod=temelist

WCED. (1987). Our common future. Oxford: Oxford University Press.

Weaver, D. B. \& Lawton, L. J. (2013). Resident perceptions of a contentious tourism event. Tourism Management, 37, $165-175$.

WTO. (2001). The concept of sustainable tourism. http://www.world-tourism.org/sustainable/concepts.htm

Yoon, Y., Gursoy, D. \& Chen J. S. (2001).Validating a tourism development theory with structural equation modeling. Tourism Management, 22, 363-372.

Zolfani, S. H., Sedaghat M., Maknoon, R. \& Zavadskas, E. K. (2015) Sustainable tourism: a comprehensive literature review on frameworks and applications. Economic Research-Ekonomska Istraživanja, 28(1), 1-30.

Table1: Measurement Model Properties

\begin{tabular}{|c|c|c|c|}
\hline Variables & $\begin{array}{l}\text { Factor } \\
\text { loadings }\end{array}$ & $\begin{array}{l}\text { Average } \\
\text { variance } \\
\text { extracted }\end{array}$ & $\begin{array}{l}\text { Cronbach's } \\
\text { Alpha }\end{array}$ \\
\hline Community attachment (CA) & & 0,76 & 0,96 \\
\hline The settings and facilities provided by this community are the best & 0,86 & & \\
\hline I prefer living in this community over other communities & 0,84 & & \\
\hline I enjoy living in this community more than other communities & 0,92 & & \\
\hline I identify the living in this community & 0,86 & & \\
\hline I feel that this community is a part of me & 0,90 & & \\
\hline Living in this community says a lot about who I am & 0,87 & & \\
\hline Living in this community means a lot to me & 0,89 & & \\
\hline I am very attached to this community & 0,90 & & \\
\hline I feel a strong sense of belonging to this community & 0,87 & & \\
\hline Many of my friends/family prefer this community over other communities & 0,74 & & \\
\hline Community involvement (CI) & & 0,80 & 0,92 \\
\hline I participate in sustainable tourism-related activities & 0,86 & & \\
\hline I support research for the sustainability of this community & 0,90 & & \\
\hline I am involved in the planning and management of sustainable tourism in this community & 0,92 & & \\
\hline I am involved in the decision-making for the sustainable tourism of this community & 0,89 & & \\
\hline Perceived benefits (PB) & & 0,72 & 0,96 \\
\hline Increase employment opportunities & 0,81 & & \\
\hline Increase shopping opportunities & 0,85 & & \\
\hline Increase the revenues from visitors for local governments & 0,86 & & \\
\hline Increase business for local people and small businesses & 0,86 & & \\
\hline Increase opportunities for leisure and tourism & 0,89 & & \\
\hline Improve the conditions of roads and other public facilities & 0,86 & & \\
\hline Provide an incentive for the preservation of local culture & 0,88 & & \\
\hline Develop cultural activities by local residents & 0,87 & & \\
\hline Increase cultural exchanges between visitors and residents & 0,86 & & \\
\hline Increase positive effects on cultural identity & 0,75 & & \\
\hline Perceived costs (PC) & & 0,66 & 0,74 \\
\hline Increase the prices of goods and services & 0,794 & & \\
\hline Increase environmental pollution & 0,891 & & \\
\hline Increase conflicts between visitors and residents & 0,752 & & \\
\hline Support for sustainable tourism development (STD) & & 0,82 & 0,95 \\
\hline I support the development of community-based sustainable tourism initiatives & 0,88 & & \\
\hline I participate in sustainable tourism-related plans and development & 0,93 & & \\
\hline I participate in cultural exchanges between local residents and visitors & 0,91 & & \\
\hline I cooperate with tourism planning and development initiatives & 0,94 & & \\
\hline I participate in the promotion of environmental education and conservation & 0,89 & & \\
\hline
\end{tabular}

Table 2: The Basic Model (Standardized)

\begin{tabular}{|c|c|c|c|c|c|}
\hline Path & & Estimate & S.E. & C.R. & $\mathbf{P}$ \\
\hline PB & $<---C A$ & 0,089 & 0,031 & 2,597 & 0,009 \\
\hline PB & $<---\quad$ CI & 0,541 & 0,034 & 13,299 & 0,000 \\
\hline PC & $<---$ CA & $-0,083$ & 0,039 & $-2,002$ & 0,045 \\
\hline PC & $<---\quad$ CI & 0,19 & 0,046 & 3,664 & 0,000 \\
\hline PC & $<---$ & $-0,105$ & 0,049 & $-2,237$ & 0,025 \\
\hline STD & <--- & 0,007 & 0,035 & 0,256 & 0,798 \\
\hline STD & $<---$ & 0,236 & 0,041 & 6,514 & 0,000 \\
\hline STD & <--- & $-0,139$ & 0,035 & $-5,08$ & 0,000 \\
\hline STD & $<---$ & 0,565 & 0,054 & 14,225 & 0,000 \\
\hline
\end{tabular}


Table 3: The Results of Multi-Group Analysis Panel (a) Multigrup Comparison

\begin{tabular}{|c|c|c|c|c|c|}
\hline $\begin{array}{l}\text { models and } \\
\text { paths }\end{array}$ & $\begin{array}{l}\text { Chi } \\
\text { square }\end{array}$ & $\begin{array}{l}\text { freedom } \\
\text { degrees }\end{array}$ & $\begin{array}{l}\Delta \text { Chi } \\
\text { square }\end{array}$ & $\Delta \mathrm{DF}$ & \\
\hline $\begin{array}{l}\text { unconstrained } \\
\text { model }\end{array}$ & 2720,228 & 939 & & & \\
\hline $\begin{array}{l}\text { Full constrained } \\
\text { model }\end{array}$ & 2623,718 & 904 & 96,51 & 35 & $P<0,05$ \\
\hline PB <--- CA & 2623,718 & 905 & 96,51 & 34 & $P<0,05$ \\
\hline$<---\quad$ CI & 2623,971 & 905 & 96,257 & 34 & $P<0,05$ \\
\hline$<---$ CA & 2632,29 & 905 & 87,938 & 34 & $P<0,05$ \\
\hline$<---\quad$ CI & 2626,28 & 905 & 93,948 & 34 & $P<0,05$ \\
\hline$<---$ & 2629,084 & 905 & 91,144 & 34 & $P<0,05$ \\
\hline STD <--- & 2632 & 905 & 88,228 & 34 & $P<0,05$ \\
\hline STD <--- & 2629,08 & 905 & 91,148 & 34 & $P<0,05$ \\
\hline STD <--- & 2624,03 & 905 & 96,198 & 34 & $P<0,05$ \\
\hline
\end{tabular}

Panel (b) male and female models

\begin{tabular}{|c|c|c|c|c|c|}
\hline \multirow{2}{*}{ Path } & & \multicolumn{2}{|c|}{ Female standardized model } & \multicolumn{2}{|c|}{ Male standardized model } \\
\hline & & Estimate & $\mathbf{P}$ & Estimate & $\mathbf{P}$ \\
\hline PB & $<---$ CA & 0,087 & 0,011 & 0,098 & 0,025 \\
\hline PB & \multirow[t]{2}{*}{$<---$} & 0,511 & 0.00 & 0,561 & 0.00 \\
\hline \multicolumn{5}{|l|}{$\mathrm{CI}$} & \\
\hline PC & --- CA & $-0,219$ & 0,01 & 0,016 & 0,768 \\
\hline PC & \multirow[t]{2}{*}{$<---$} & 0,318 & 0.00 & 0,108 & 0,007 \\
\hline CI & & & & & \\
\hline PC & \multirow[t]{2}{*}{$<---$} & $-0,266$ & 0.00 & 0,003 & 0,96 \\
\hline PB & & & & & \\
\hline STD $<-$ & $\mathrm{CI}$ & 0,335 & 0.00 & 0,154 & 0.00 \\
\hline STD $<-$ & PC & $-0,063$ & 0,011 & $-0,189$ & 0.00 \\
\hline STD $<-$. & $\mathrm{PB}$ & 0,524 & 0.00 & 0,619 & 0.00 \\
\hline
\end{tabular}

Table 4: Comparative Results

\begin{tabular}{|c|c|c|c|}
\hline path & Choi and Murray & Lee & Ours \\
\hline PB <--- CA & 0.300 & 0,4 & 0,089 \\
\hline$<---\quad$ CI & -0.199 & 0,25 & 0,541 \\
\hline$<---$ CA & -0.236 & $0,06^{*}$ & $-0,083$ \\
\hline$<---\quad$ CI & 0.285 & $-0,07^{*}$ & 0,19 \\
\hline PC <--- PB & & & $-0,105$ \\
\hline STD <--- $\quad$ CA & 0.117 & & $0,007^{*}$ \\
\hline STD <--- & $-.096^{*}$ & & 0,236 \\
\hline STD <--- & -0.378 & $-0,24$ & $-0,139$ \\
\hline STD <--- & 0.424 & 0,69 & 0,565 \\
\hline
\end{tabular}

*not significant 


\section{Figure 1: The mixed model MM}

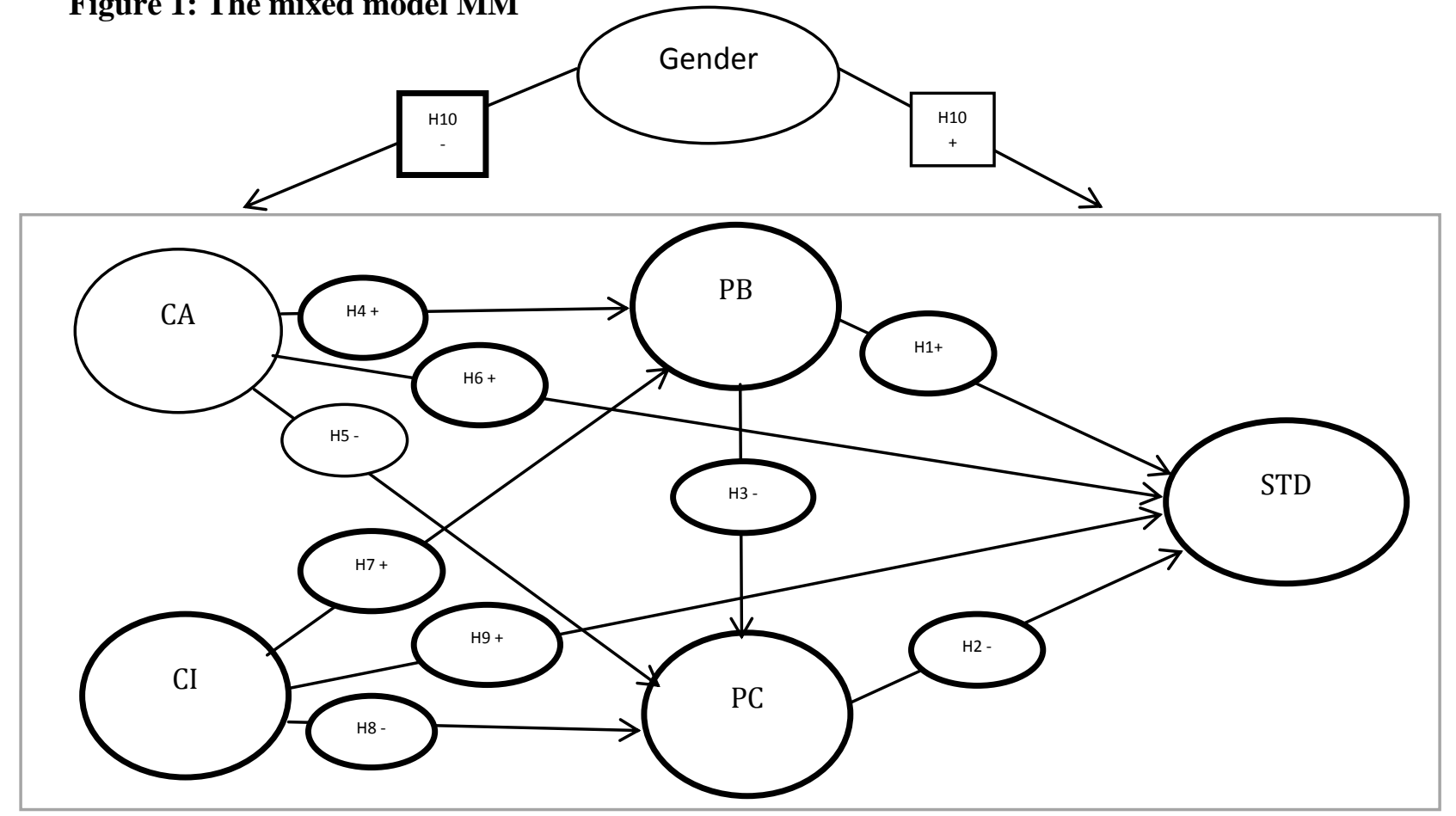

* CA: community attachment, CI: community involvement, PB: perceived benefits, PC: Perceived costs and STD: support for sustainable tourism.

Figure 2: The mixed model MM after testing

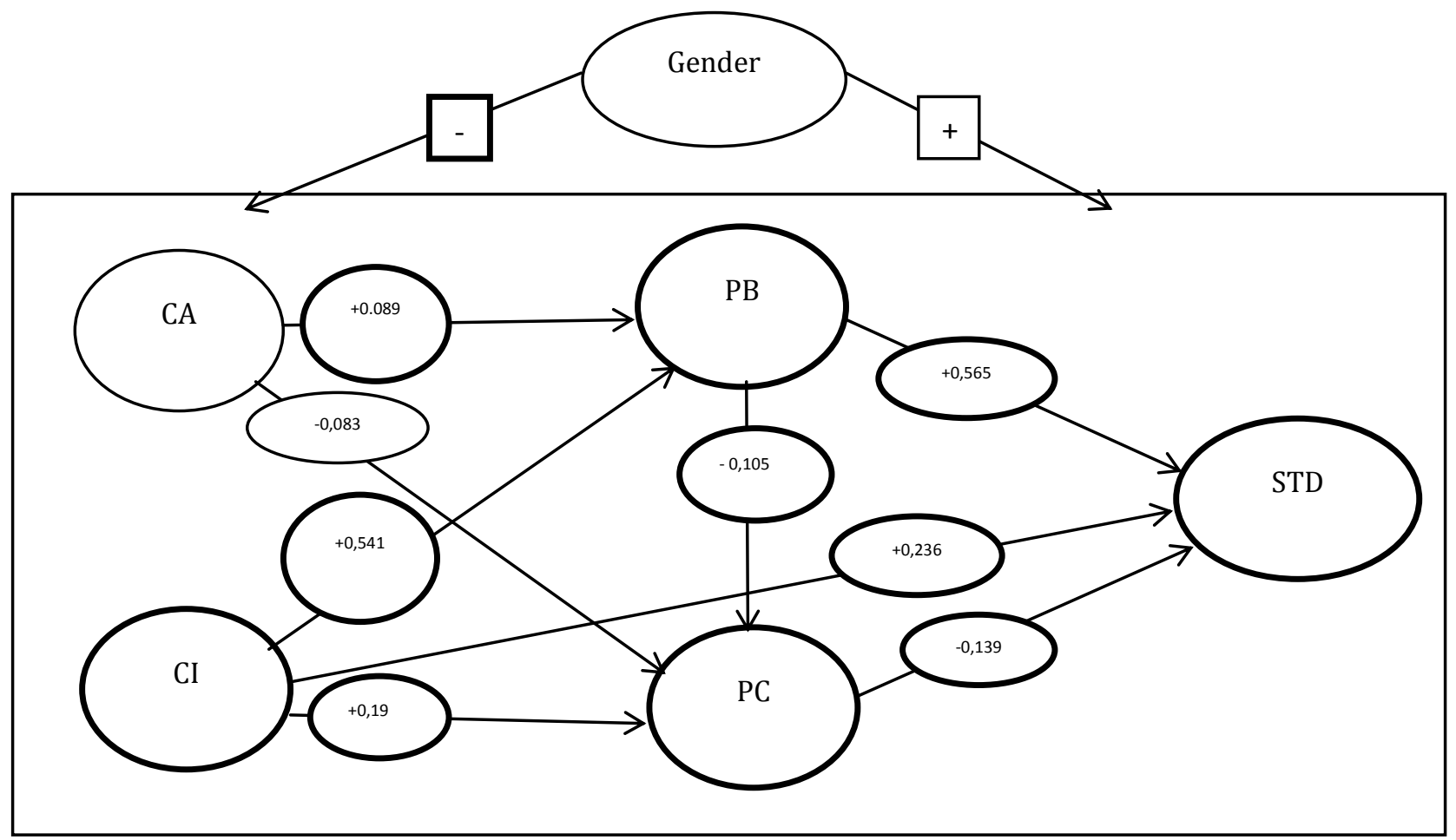

* CA: community attachment, CI: community involvement, PB: perceived benefits, PC: Perceived costs and STD: support for sustainable tourism. 